\title{
Authenticating El Dorado: Frustrated Knowledge Production in Walter Ralegh's Discoverie of Guiana
}

DOI:

10.1017/S0165115319000548

\section{Document Version}

Accepted author manuscript

Link to publication record in Manchester Research Explorer

\section{Citation for published version (APA):}

Winchcombe, R. (2019). Authenticating El Dorado: Frustrated Knowledge Production in Walter Ralegh's

Discoverie of Guiana. Itinerario, 43(3), 443-465. https://doi.org/10.1017/S0165115319000548

\section{Published in:}

Itinerario

\section{Citing this paper}

Please note that where the full-text provided on Manchester Research Explorer is the Author Accepted Manuscript or Proof version this may differ from the final Published version. If citing, it is advised that you check and use the publisher's definitive version.

\section{General rights}

Copyright and moral rights for the publications made accessible in the Research Explorer are retained by the authors and/or other copyright owners and it is a condition of accessing publications that users recognise and abide by the legal requirements associated with these rights.

\section{Takedown policy}

If you believe that this document breaches copyright please refer to the University of Manchester's Takedown Procedures [http://man.ac.uk/04Y6Bo] or contact uml.scholarlycommunications@manchester.ac.uk providing relevant details, so we can investigate your claim.

\section{OPEN ACCESS}


Authenticating El Dorado: Frustrated Knowledge Production in Walter Ralegh's

\title{
Discoverie of Guiana
}

\begin{abstract}
This article takes a fresh approach to Walter Ralegh's published account of his voyage to Guiana, The Discoverie of the Large, Rich, and Bewtiful Empyre of Guiana (1596), using it as a case study through which to explore the fragility of sixteenth-century processes of knowledge production about new lands. The article revisits this famous account in order to scrutinize in more detail the types of evidence Ralegh used to support his claims that a rich and powerful empire laid ready to be conquered by the English in the Amazon. This new analysis of Ralegh's narrative highlights the continued centrality of reputational models of authority in early modern travel literature and examines the types of evidence that could be employed by writers to support their suppositions when witness testimony was lacking. Ralegh's narrative illustrates that systems of knowledge production centred on the New World were, at the end of the sixteenth century, still in a state of flux. New ideas about what constituted credible knowledge, from first-hand experience to the collection of material artefacts, competed with older frameworks of authentication and authority. By examining knowledge production in frustration, and by dissecting Ralegh's failure to present a believable vision of El Dorado, this article throws into starker relief the many pitfalls and difficulties that beset those who attempted to present new and credible knowledge about the New World.
\end{abstract}

\section{Keywords}

Knowledge production; eye-witnessing; exploration; Walter Ralegh; New World. 


\section{Introduction}

In 1595 Sir Walter Ralegh set sail for the New World, aiming to discover and secure for the English crown the Empire of Guiana and 'the great and Golden Citie of Manoa' which was known amongst the Spanish as El Dorado. ${ }^{1}$ After a tortuous expedition in which Ralegh and his men not only failed to penetrate the fabled Empire of Guiana, but also failed to procure direct proof of the wealth of Guiana's principal city Manoa, Ralegh returned home to face his critics, of which there were many. ${ }^{2}$ In an attempt to stifle the many negative rumours that greeted him on his return home, including the suggestion that he had never even set foot in America, Ralegh composed a narrative of his voyage that was published in 1596 under the title The Discoverie of the Large, Rich, and Bewtiful Empyre of Guiana (henceforth The Discoverie). As Ralegh made clear in his address to the reader, the text's purpose was to provide answer to the 'malicious slaunder' that had circulated since his return home and to assert the claim that the American provinces that he had discovered would provide Queen Elizabeth I and the English kingdom 'with no lesse quantities of treasure, then the King of Spayne hath in all the Indies' ${ }^{3}$

Ralegh's text was thus simultaneously promotional and apologetic. In order to dissuade his critics and convince potential investors that the Empire of Guiana did exist, Ralegh crafted a narrative that he hoped would prove his claims and testify to his reliability as an explorer and author. The problem for Ralegh, however, was that he had not actually seen the city of El Dorado, nor witnessed its fabulous riches. Ralegh's narrative is also therefore an example of knowledge production in frustration. Ralegh had been unable to find El Dorado and had thus not witnessed the very thing he set out to prove existed. Ralegh's account of his voyage, then, represents a compelling case study through which to explore sixteenth-century processes of knowledge accumulation, and through which to dissect the fragility of some forms of evidence at the turn of the seventeenth century. Ralegh's attempts to prove the existence of a Guianan 
El Dorado through a variety of methods illustrate the changing nature of what constituted accurate knowledge and believable suppositions, and the fluctuating beliefs surrounding how new information about new lands should be presented to a critical reading public at the close of the sixteenth century.

Scholars of early modern travel have long noted the prevalence of declarations of experience in travellers' accounts detailing discoveries in the New World. ${ }^{4}$ As Karen Kupperman has argued, those writing about their American exploits all made the same claim, that 'eyewitness authority supersedes all other kinds of knowledge' ${ }^{5}$ In 1534, for example, Jacques Cartier, a Breton explorer who first claimed Canada for the French, declared that 'experience is the master of all things', whilst the famed English explorer John Smith claimed that experience was 'the very ground of reason'. ${ }^{6}$ Experience, then, was at the very heart of new knowledge about the Americas in the early modern period. The scholarship that has emphasised the rise of what Anthony Pagden has dubbed 'autopic authority', has largely focused on texts in which the author had successfully 'witnessed' the thing they were describing, whether that be Cartier's sixteenth-century description of Canada or John Smith's seventeenth-century account of life in early Virginia. In contrast, this article, by focusing on Ralegh's narrative, traces what happened when explorers did not witness the things they set out to prove existed to their readers back home. What did authors of travel narratives do when they could not obtain convincing eye-witness testimony, testimony that had become the hallmark of knowledge production about the New World? What other types of evidence could be used to corroborate new ideas about the lands across the Atlantic?

With the influx of information from the Americas, came new forms of collection and collation. Historians, compilers, and editors broadened the spectrum of source material that could be used as evidence. Aside from learned classical texts and the Bible, which as Anthony Grafton has argued proved remarkably resilient in the wake of the European 'discovery', 
letters, proclamations, maps, travelogues, journals, intelligence reports, and even material objects were also considered relevant, and in many cases reliable, forms of information. ${ }^{7}$ Despite these newer forms of information, Ralegh's text highlights that different types of evidence were not created equal. Instead, by examining Ralegh's narrative, it becomes clear that there was a sliding scale of what evidence was considered most convincing. At the top of this hierarchy of proof was autopsy, being followed by material proof, and the compilation of fragmentary information from other contemporary sources.

By tracing the various strategies employed by Ralegh to authenticate his belief in a Guianan El Dorado, and by assessing the ultimate failures of these techniques, this article also illustrates how crucial specific forms of eye-witnessing were to the acquisition and acceptance of new information about exotic lands in the early modern period. Just as different types of evidence were not created equal, nor were all forms of eye-witness testimony. In contrast to recent scholarship that has argued that experience became the defining feature of credible witness testimony in sixteenth-century travel literature, this article contends that Ralegh's struggles to present reliable eye-witness testimony, both first-hand and second, highlight the continued centrality of reputational models of authority. ${ }^{8}$ Whilst the importance of reputation in early modern society has been explored by economic historians and scholars of the history of science, less has been said about the role played by reputation in travel narratives detailing new discoveries. ${ }^{9}$ As Craig Muldrew has convincingly argued, reputation for honesty and reliability was of 'great social importance' in the early modern period. ${ }^{10}$ Ralegh's inability to rehabilitate his reputation for being untrustworthy, alongside his reliance on the contested and dubious testimony of England's enemy, the Spanish, undermined his vision of a Guianan El Dorado. The appeal to direct experience was not enough to make eye-witness testimony credible; the reliability of eye-witness accounts was also subject to the good reputation of the person doing the witnessing. To be a successful eye-witness at the end of the sixteenth century, 
then, reputation and experience had to coexist. In order to mitigate the ethical problems with the eye-witness testimony presented in the narrative, Ralegh was forced to utilise other supporting evidence, from illicitly procured Spanish secrets, to material evidence that would prove the existence of gold, to form a believable and coherent narrative that would be acceptable to his English readers. ${ }^{11}$

In approaching The Discoverie in this manner this article moves beyond pervasive Ralegh-centric and El Dorado-centric readings of the narrative, placing it instead in a wider context of sixteenth-century systems of knowledge accumulation and the problems and difficulties associated with them. ${ }^{12}$ In doing so it also moves away from assessing Ralegh's failures as an explorer, to evaluate his shortcomings as an author. In what follows, I dissect Ralegh's failures at presenting credible evidence of a Guianan El Dorado, highlighting the precarity of knowledge production about the New World at the end of the sixteenth century and the continued importance of reputation in early modern models of eye-witnessing. In doing so, this article argues that systems of knowledge production in the century after the European 'discovery' of America were in a state of flux, as new ideas about what constituted credible knowledge competed with older frameworks of authentication and authority. ${ }^{13}$ This article is split into three parts that elucidate Ralegh's participation in new forms of knowledge authentication and the ultimate failures of his methods. The first maps how Ralegh came to believe in a Guianan El Dorado and establishes the sources of information on which this belief was based; the second assesses the credibility of Ralegh's sources of information about El Dorado, particularly the eye-witness testimony of a Spaniard named Juan Martín de Albújar who had claimed to have seen the city first-hand; and the third establishes how Ralegh attempted to mitigate the problems associated with Martín's account by utilising innovative yet highly contingent forms of evidence. 


\section{A Guianan El Dorado}

When Ralegh set sail for South America in early 1595 it was not with the intention of discovering the mythical golden kingdom of El Dorado. Instead, Ralegh hoped to discover and secure for the English Crown the city of Manoa, which he believed to be rich in precious commodities, particularly gold. It was only during his voyage that the two golden lands, El Dorado and Manoa, became conflated. It was this conflation that dictated and shaped the ways Ralegh attempted to authenticate his beliefs and the types of sources he used to do this. In order to understand the strategies employed by Ralegh to convince his readers of the veracity of a Guianan El Dorado, then, it is first critical to understand how he came to believe in the golden kingdom's existence in the first place.

At first glance, Ralegh's description of Manoa in The Discoverie is strikingly similar to other sixteenth-century accounts of El Dorado. Ralegh described Manoa as having 'more abundance of Golde then any part of Peru'.${ }^{14}$ According to Ralegh, the city was founded on a 'lake of salt water', and the elite men who pledged allegiance to the native chief were regularly anointed all over with a type of white balsam, after which 'certaine servants of the Emperor, having prepared gold made into fine powder blow it thorow hollow canes upon their naked bodies'. ${ }^{15}$ In a similar description of El Dorado, centred on the Muisca territories of modernday Colombia where the legend began in the 1530s, the Spanish historian and poet Juan de Castellanos explained how the local king 'with no clothes' made offerings at a sacred lake. ${ }^{16}$ His body was anointed all over with resin and gold dust, 'shining like a resplendent ray of the sun'. ${ }^{17}$ Despite these similarities in description, from a close reading of The Discoverie it is clear that Ralegh's vision of Manoa, and its connection to the wider El Dorado story, was by no means fully formed before he left for America. 
In the dedication to Charles Howard and Robert Cecil, Ralegh explained how 'many years since' he had 'knowledge by relation of that mighty, rich and bewtifull Empire of Guiana' and its principal city Manoa. ${ }^{18}$ This 'relation' came from Pedro Sarmiento de Gamboa, an expert in Inca history and a prisoner of the English court in the late 1580s. ${ }^{19}$ As Ralegh would learn from his many conversations with his prisoner, Sarmiento, having been a commander in the Spanish campaign to capture the last Inca, Tupac Amaru, was an expert in the history of the Incan Empire and its apparently lost stores of gold. ${ }^{20}$ Whilst it is likely that Ralegh learned of a kingdom rich in hidden Incan treasure from Sarmiento, it is less clear whether he also learned from him the wider story of El Dorado. In fact, and as we shall see, Ralegh appears to have acquired information on El Dorado from an entirely different Spanish source once he arrived in the New World in 1595.

The only other information Ralegh appeared to have regarding Manoa and the empire of Guiana, prior to leaving England in 1595, was gathered by Captain Jacob Whiddon the previous year. Whiddon had been involved with the American projects of Ralegh's half-brother Sir Humphrey Gilbert in the late 1570s and probably entered Ralegh's service as a captain sometime after Gilbert's death at sea in $1583 .{ }^{21}$ Ralegh recorded that he had sent Whiddon to the New World in 1594 to 'get knowledge of the passages'. The Discoverie contains little detail about the information with which Whiddon returned, save for the suggestion by Ralegh that Whiddon's intelligence about the location of Guiana was incorrect as the country turned out to be ' 600 . English miles further from the sea' then he was 'made beleeve it had beene'. ${ }^{22}$ Whiddon did not return to England in 1594 with a description of Manoa, but simply with a vague notion of where the city might be found.

Ralegh lacked specific details about Manoa prior to the voyage of 1595, and he also appeared to be unaware that the city was known amongst the Spanish by another name. Sarmiento may have told Ralegh about a legendary golden city that was named Manoa by the 
native inhabitants and home to the lost treasure of the Inca Empire, but it was from another Spaniard, on arrival in America, that he learned that this rich and prosperous land had been dubbed 'El Dorado' by the Spanish. Ralegh and his men arrived in Trinidad on 22 March 1595, having left England in February of the same year. Ralegh explained his reasons for remaining in Trinidad, rather than setting out immediately for the attempted conquest of Guiana. Firstly, Ralegh wished to exact revenge on the island's governor, Antonio de Berrío, who had captured a number of Whiddon's men during the reconnaissance mission of the previous year. Secondly, Ralegh also intended to garner more information on Guiana from the Spaniards who had been involved in earlier voyages to discover the hidden empire, suggesting once again that Ralegh's information about Guiana prior to leaving England was relatively scant. ${ }^{23}$ After receiving a number of Indian visitors aboard his ship who complained of Spanish mistreatment, Ralegh decided to take the newly established Spanish city of St Joseph, eventually capturing Berrío and setting the new city alight. ${ }^{24}$ It was from his influential prisoner that Ralegh seems to have extracted the description of Manoa set forth in The Discoverie.

Berrío had himself been an obsessive seeker of mythical golden kingdoms, undertaking a variety of voyages in the 1580 s. His initial searches for these hidden golden lands, like those of others before him, focused on the lands around the Muisca territories where the legend of El Dorado had begun. Setting out from Bogotá in 1584, Berrío's first voyage explored the regions surrounding the Casanare and Meta rivers. During this voyage, local Achagua Indians told Berrío to focus his search for El Dorado on the far side of the Orinoco river instead. It was in this region, so the Indians told Berrío, that a land rich in gold and precious stones and home to a magnificent lake called Manoa could be found. This revelation thus pushed Berrío and his men further eastward in search of a golden land named Manoa. ${ }^{25}$ By 1590, after much additional exploration around the Orinoco, Berrío came to the conclusion that the passage into El Dorado, or Manoa, as it was now known, was located at the confluence of the Orinoco and 
Caroní rivers. By the time Ralegh arrived in the New World, then, the notion that El Dorado could be found in the vicinity of the Caroní, rather than in the regions of the Muisca federation, had solidified. The name Manoa had also become synonymous with that of El Dorado in the minds of Berrío and his fellow Spaniards. Despite this, Ralegh appears to have been entirely unaware of this wider context. Whilst the conflation of El Dorado and Manoa had taken place for Berrío in the late 1580s, for Ralegh the moment of attachment occurred after he read the testimony of Juan Martín de Albújar, a Spaniard who claimed to have seen Manoa first-hand. ${ }^{26}$ This instance of conflation is critical as it went on to dictate the strategies that Ralegh employed to authenticate his account to his sceptical readers back home.

Martín had been a soldier during Pedro Maraver de Silva's ill-fated expedition to find El Dorado in 1569. During this voyage the native inhabitants of the lower Orinoco had reportedly taken Martín captive. ${ }^{27}$ According to Ralegh, it was Martín's testimony of his time in Indian captivity that convinced Berrío to continue his search for El Dorado in the lands surrounding the Caroní river. ${ }^{28}$ Martín, as Ralegh explained to his readers, was blindfolded by his captors and taken to the city of Manoa where he lived for seven months. Martín gained the favour of the native chief and was allowed to return to his own country with as much gold as he could carry. Unfortunately, Martín was robbed of all his treasure, save for two gourds filled with beads of gold. Martín eventually made his way to San Juan in Puerto Rico where an account of his time in Manoa was, according to Ralegh, recorded at the chancery. It was from this record, of which Berrío purportedly had a copy, that Ralegh learned of the story and also of Manoa's connection to El Dorado. ${ }^{29}$

The link between Martín's written testimony and Ralegh's description of Manoa is easy to miss in The Discoverie. The only potential reference to Ralegh actually having read this written account for himself comes directly after his account of Martín's time in Manoa and prior to his description of the ritual of covering elite men in gold powder. In the sentence 
preceding this description, Ralegh claimed, 'those Guianians and also the borderers, and all others in that tract which I have seen are marveylons great drunkardes' (my emphasis). ${ }^{30}$ Coupled with the fact that Martín was the only person thought to have seen Manoa first-hand, it is highly likely that Ralegh's description of Manoa, which closely echoed Spanish descriptions of El Dorado, was derived from Martín's testimony. It was also from Martín's account that Ralegh learned the name El Dorado. As he told his readers it was Martín 'that christened the citie of Manoa, by the name of El Dorado.${ }^{31}$ It would seem, then, that Ralegh's El Dorado was not an extension of the earlier story of a golden Muisca chief but an original tale of an Amazonian golden city. El Dorado, in Ralegh's mind at least, was a golden city located in the hidden empire of Guiana and Juan Martín was the only person to have ever witnessed its riches first hand.

\section{A Problematic Eye-Witness}

The process of transmitting this new and intriguing development to an English readership was by no means straightforward for Ralegh. By the time he came to write his narrative in the 1590s, what constituted credible testimony had radically changed. Prior to the European 'discovery' of the New World, autopsy in travel writing was not a necessity. As Mary B. Campbell has argued, before the Renaissance overseas travel among Europeans was so rare that travel writers could 'lie with authority'. ${ }^{32}$ They could also rely on the works of classical authorities to help inform their interpretations of far-flung countries and cultures. ${ }^{33}$ With the 'discovery' of America, however, classical texts lost much of their authority, with first-hand experience becoming the new standard of authentication for early modern travel writers. Eyewitness testimony was thus an increasingly crucial ingredient of accurate and credible travel writing. ${ }^{34}$ 
Juan Martín, for a variety of reasons, was a highly unreliable witness. As we shall see, his apparent 'experience' of Manoa was decidedly suspect and Ralegh's invocation of his story thus profoundly problematic. Martín's account of his time in Manoa is shrouded in mystery and controversy. It is unclear exactly what the text was that Ralegh claimed to have had access to, how Berrío had acquired it in the first place, and whether or not it was actually composed by Martín himself. What is clear, however, is that the tract Ralegh had purportedly read did not square with other contemporary accounts of Martín's time in captivity. Juan de Castellanos, the Spanish poet and historian who had detailed the Muisca ritual of El Dorado, had also provided his readers with information on Martín's time in the region surrounding the Orinoco river. In his epic poem, Elegías de Varones Ilustres de Indias (Elegies of Illustrious Men of the Indies), Castellanos gave a thorough account of Spanish colonial activity in the regions of modern-day Colombia and Venezuela, including Pedro Maraver de Silva's attempt to find the hidden city of El Dorado which culminated in Juan Martín's capture by Amerindians. ${ }^{35}$

According to Castallanos, Martín never visited Manoa during his time in captivity and nor were the Amerindians who took him prisoner rich in gold and other precious materials. ${ }^{36}$ In fact, the natives that Martín spent time with were described by Castallanos as 'a poor people', lacking in all resources and treasure, save for a small amount of gold that was mixed with copper. ${ }^{37}$ John Hemming has argued that the story of Juan Martín's time in El Dorado was no doubt embellished and embroidered over time to make it more appealing to adventurous Spaniards. ${ }^{38}$ Going one step further, V. S. Naipaul has suggested that Martín may never have even existed, his story being a mere invention. ${ }^{39}$ Like many other remarkable tales told about the American lands in the sixteenth century, then, from the legend of the Fountain of Youth, to the lost golden cities of Cíbola and El Paitití, Martín's El Dorado story can be seen as another example of the European myth-building process that was so characteristic of the encounter between the Old World and the New. ${ }^{40}$ 
The fact that Martín's story also seemed to be missing some crucial information also further undermined its reliability. As Ralegh explicitly told his readers, Martín had been blindfolded by his captors and therefore could not recount the exact location of the golden city. Nor could Martín provide any physical proof of Manoa's existence, as according to the record, he had inconveniently (or for the more sceptical, conveniently) been robbed of all the treasure he had been given on his release. ${ }^{41}$ It is possible that these details were added to the story by those who had created it in order to excuse the fact that, despite this apparent eye-witness testimony from a man who had spent an extended period of time in El Dorado, the city still remained stubbornly hidden. As will be discussed in more detail later, Ralegh attempted to mitigate these omissions by providing his own physical proof for the veracity of Martín's story through the testing of ore samples brought back from the New World. As Martín is said to have died soon after his arrival in Puerto Rico it is almost impossible to deduce whether or not he was responsible for the story or whether his account of his time in captivity was embellished, or created, by others and then retrospectively attached to the legend of El Dorado. ${ }^{42}$ It is, of course, entirely possible that Ralegh's readers, and perhaps Ralegh himself, were unaware of the controversies surrounding Martín's tale. This did not mean, however, that Martín's eyewitness testimony would have been credible to an English readership, whether factually accurate or not.

One of the problems with Ralegh's presentation of Martín's story, aside from the fact it may have been a complete fabrication, was that he did not record it verbatim. From Ralegh's rendering of the tale the reader is given no indication as to its faithfulness to the original text. He does not quote directly from the textual source, providing instead a summary of what he considered to be the most salient points of the story. If Ralegh did read the story for himself from the tract from San Juan de Puerto Rico, as he implicitly suggested he did, it could be assumed that he read it in Spanish and translated it into English, summarising it for his readers. 
Whilst there were a variety of cultures of translation that coexisted in sixteenth-century Europe, for those engaged in producing translations of colonial texts into English, providing an accurate and faithful rendition of the original appears to have been critical to establishing the authenticity of the translated work. ${ }^{43}$ Nowhere is this clearer than in the work of Richard Hakluyt, the most influential and avid promoter of English overseas activity and colonial expansion in the sixteenth century. From Hakluyt's earliest translations it is clear that he was conscious that his work be seen as an accurate reflection of the original source material. Not only did Hakluyt often take the time, and the added expense, of printing both the translation and original text together, he also explained in the prefatory material how he set about translating a foreign text into English. ${ }^{44}$ In his address to the reader in the 1589 edition of The Principal Navigations, Voyages, Traffiques and Discoveries of the English Nation, Hakluyt explained that whatever testimony he found, whether 'strange or naturall' he recorded it 'word for word', citing the original author's name and the page of the book it could be found in. ${ }^{45}$ Hakluyt revered the authority of the printed book and sought, therefore, to produce faithful renditions of the eye-witness testimony he translated, even if it meant presenting information that appeared contradictory to what he had written previously. ${ }^{46}$ In contrast, Ralegh appears to have given little thought to his presentation of Juan Martín's apparent eye-witness testimony. Ralegh did not make it particularly clear to his readers that he had actually read Martín's account for himself, save for one potential reference to the manuscript when discussing the drunkenness of the native Guianans, and nor did he provide his readers with direct quotations from the source or a transcript of the original Spanish text. ${ }^{47}$

Aside from the unsubstantiated, ambiguous, and openly contested nature of Martín's account, and Ralegh's presentation of it, the fact that Martín was a Spaniard, and his tale appeared to have been relayed in some form to Ralegh via the Spanish prisoner Berrío, no doubt further undermined the story's credibility. ${ }^{48}$ The sixteenth century witnessed the 
emergence of new understandings of what constituted a reliable witness, especially in the context of overseas exploration. Prior to this period a witness's credibility was largely defined by his or her reputation and standing within a community. Andrea Frisch, in her innovative study of the changing nature of witness testimony, has dubbed this medieval figure 'the ethical witness' ${ }^{49}$ In the mid-sixteenth century, however, new forms of credible testimony came to the fore which prioritised the witness's experiences over his or her reputation. By the time Ralegh was writing in the 1590 s, ethics in witness testimony had been given a secondary position to epistemology. ${ }^{50}$ That does not mean, however, that the reputation of the witness amongst the community that received the testimony was no longer relevant. In fact, reputation continued to shape all facets of early modern life, whether in relation to economic status, sexual morality, codes of genteel and scientific conduct, and of course, knowledge production regarding nonEuropean lands. $^{51}$

It is clear from sixteenth-century English translations of Spanish eye-witness testimony on the New World that the reputation, and indeed the nationality, of the witness remained of critical importance to notions of reliability and authenticity. In late sixteenth-century prefaces to English translations of Spanish texts about the New World, translators explicitly attempted to justify the publication of a text written by England's principal enemy and establish the reliability of the information contained within it. One way that English translators achieved this was by implying or, in some cases, explicitly claiming that they had received these Spanish texts by illicit means. ${ }^{52}$ A clear example of this technique can be seen in the preface to Richard Hakluyt's third volume of The Principal Navigations. In the text's first edition, published in 1589, Hakluyt had in many ways circumvented this problem by focusing his attention on accounts written by Englishmen. However, by the time his second edition was released, with the third volume on the Americas appearing in London in 1600, Hakluyt had decided to include a range of Spanish sources in order to make English knowledge of the New World more 
complete. ${ }^{53}$ Whilst he wished to provide his readers with the most up-to-date information on the New World, he was still careful to avoid praising Spanish overseas achievements. One way that he managed this was by claiming the texts he had translated from Spanish were illicitly procured.

In his dedication to Robert Cecil, who was also the patron of Ralegh's Guiana project, Hakluyt cleverly used continued English hostilities with Spain to his advantage. According to Hakluyt, since the war with Spain 'all their secrets of the West Indies' had fallen into the hands of the English. ${ }^{54}$ By sacking Spanish towns and cities, and by taking Spanish ships, the English had procured a number of documents that would be useful for their own explorative and colonial ambitions. Hakluyt, in his role as one of the most outspoken and well-informed advocates of English overseas expansion, endeavoured to publish 'such secrets' of the Spanish, not merely to 'annoy' England's enemy, but also to 'availe' his fellow countrymen in their New World projects. ${ }^{55}$ These Spanish texts, then, were not intended for English eyes. The objective of the Spanish authors who created these texts was ostensibly to provide credible information on the New World to their compatriots. By intercepting these documents, Englishmen such as Hakluyt could access this credible testimony without having to explain and justify their reproduction. As we shall explore later, Ralegh also utilised this technique in The Discoverie by including a set of captured Spanish letters that seemed to support the existence of El Dorado as an appendix to the published text. Ralegh's over-reliance on the testimony of Martín and Berrío, however, and his seemingly uncritical acceptance of their stories remained problematic, especially when considered alongside his thorough denunciation of the Spanish conquistadors he came across during the voyage.

Ralegh not only used the Spanish to corroborate his vision of a Guianan El Dorado, he also used them to justify English conquest and colonisation by demonising their behaviour. Ralegh had used the apparent bad behaviour of the Spanish towards the indigenous population 
as justification for his attack on St Joseph and his denunciation of Spanish activity in the region continued throughout his account of his time in South America. ${ }^{56}$ According to Ralegh, the Spanish took from the native men 'both their wives, and daughters daily, and used them for the satisfying of their owne lusts'. ${ }^{57}$ Ralegh also accused the Spanish of buying native women from the treacherous, man-eating Canibals, making 'great profit' from these transactions in which 'a maid of 12 or 13 yeeres' could be purchased for 'three or fower hatchets' and then sold at Margarita for fifty to one hundred pesos. ${ }^{58}$ In contrast, Ralegh portrayed the behaviour of himself and his fellow Englishmen much more positively. Unlike their Spanish counterparts, the English explorers remained entirely sexually continent. Ralegh assured his readers that neither himself nor any of his men had 'companie one or other, by violence or otherwise' or 'even knew any of their women', even though they were 'very yoong \& excellently favoured'. 59 By negatively portraying the Spanish of the region as deceitful and violent, yet simultaneously relying on their testimony to corroborate the notion of a Guianan El Dorado, Ralegh tried to have his cake and eat it; Ralegh's own credibility was reliant on him convincing his readers of the credibility of those who he also wished, and indeed needed, to discredit. ${ }^{60}$ Unsurprisingly, this strategy proved unsuccessful. Even Ralegh himself seemed to be aware of the shortcomings of this Spanish eye-witness testimony, given the great lengths he went to to corroborate the El Dorado story using a range of other forms of evidence.

\section{Corroborating Evidence?}

By conflating the Manoa of Martín's account with the wider story of El Dorado, Ralegh was able to utilise a range of evidence that seemed to support the existence of the latter. This set of evidence, then, was contingent on Ralegh's belief that Manoa and El Dorado were one and the same, and on his acceptance that Martín's story had at least some basis in fact. Spanish accounts 
of searches for El Dorado, rather than Manoa, were now useful pieces of information that could be redeployed by Ralegh in the context of his search for the lost treasure of the Inca Empire and used to mitigate the problems associated with Martín's eye-witness testimony.

The first strategy that Ralegh employed to place his voyage within this wider El Dorado narrative was his use of fragmentary evidence from contemporary Spanish accounts of the conquest of Peru. This was a methodology that Ralegh would continue to utilise in his later works, especially in his History of the World ${ }^{61}$ In the sixteenth century historical writing was increasingly cleaved from rhetoric and instead defined by a specific methodology in which fragments of evidence, derived from a wide variety of sources, were recombined into an overarching narrative of the past. ${ }^{62}$ By integrating pieces of information on the Spanish search for El Dorado, and on the lost treasure of the Incas, with his own beliefs about the existence of Manoa, Ralegh attempted to illustrate to his readers that the golden city did exist, it was to be found in the vicinity of the Orinoco and Caroní rivers, and it was home to vast stores of treasure that had been transported to the region after the Spanish conquest of Peru.

The first point that Ralegh attempted to prove to his readers by using fragments of information was his theory on how the Manoans had accumulated the vast stores of gold that Martín had detailed in his account. Ralegh recognised that many 'doubtes' would arise amongst his readers as to how Guiana came to be so populous and rich in treasure. ${ }^{63}$ To assuage these doubts, Ralegh thought it 'good to make it knowen' that the Emperor reigning in Guiana was 'discended from those magnificent Princes of Peru' ${ }^{64}$ Ralegh claimed that, after the execution of his brother, 'one of the younger sonnes of Guaynacapa fled out of Peru, and tooke with him many thousands of those souldiers of the Empyre'. ${ }^{65}$ Based on what Ralegh had learned about both Peru and Manoa, he concluded that the people of Guiana 'observe the same religion, and the same forme and pollicies in government as was used in Peru, not differing in any part' ${ }^{66}$ It is once again likely that Ralegh first heard of this theory from the Inca history expert Sarmiento, 
but he also cited the work of Pedro Cieza de León and Francisco López de Gómara as evidence for this belief. ${ }^{67}$ The use of these sources, written by Spaniards close to the actions undertaken in the conquests of Mexico and Peru, would, so Ralegh hoped, make the existence of Manoa and its vast stores of treasure 'seeme more than credible'. ${ }^{68}$

In a passage taken from Gómara's Historia General de Las Indias, there are multiple references to the magnificence of Guaynacapa's court. As well as having 'nothing in his country, whereof hee had not the counterfeat in gold', Guaynacapa also had 'an infinite quantitie of silver and gold unwrought in Cuzco' which was hidden away by the Incas after the death of his son Guascar. ${ }^{69}$ The implication is that this hidden treasure was somehow transported to the new Empire of Guiana with Guaynacapa's younger son. By recombining these fragments of information, Ralegh concluded that the lost treasure of Peru became the treasure of Guiana and its capital city Manoa. To reinforce the authenticity of the information he had derived from Gómara, Ralegh employed the same method that had been utilised by his associate, Richard Hakluyt, in earlier English translations of foreign texts; Ralegh included Gómara's original Spanish, alongside his English translation of the relevant passage. ${ }^{70}$ Ironically, this attention to replicating Gómara's words accurately, further undermined Martín's story. Whilst Ralegh was able to provide clear and unambiguous references for where he found the information on Peru, he was unable to do the same for Martín's tale of Manoa, making it seem all the more likely that Ralegh had never had direct access to his testimony.

Ralegh, however, had one more set of what he thought was compelling and corroborating evidence. On his return to England in 1595, Ralegh was made aware of a set of documents that seemed to support the claims that he had been making about El Dorado. Ralegh was not the first Englishman to go in search of treasure in the region surrounding the Orinoco river. Around two months prior to Ralegh's arrival at Trinidad, Robert Dudley, the illegitimate son of Robert earl of Leicester, had already landed in Trinidad, explored the island for gold 
mines, and made his way to the Orinoco delta in search of El Dorado. Dudley's voyage had been triggered by an encounter with Captain George Popham. Popham had been involved in late 1594 with a chance capture of a vessel bound for the Canary Islands from Spain. On board, the Englishmen found an English prisoner, Captain Harper, and a series of letters written to correspondents in Spain on the subject of El Dorado and the recent Spanish searches for the hidden city. It was this information that convinced Dudley to set a course for Trinidad. Dudley's voyage, like Ralegh's, was largely unsuccessful, with Dudley setting sail for the return trip to England on either 11 or 12 March 1595, a mere ten days before Ralegh arrived in Trinidad himself. When Popham returned to England from his own adventures in the Caribbean in late 1595, he surrendered the captured Spanish documents to the Privy Council, possibly at the instruction of Robert Cecil who would have considered this correspondence to be good supporting evidence for Ralegh's project. ${ }^{71}$

Whilst Ralegh would have undoubtedly been annoyed by Dudley's voyage as it in many ways sought to beat Ralegh to the ultimate prize of El Dorado, he nonetheless recognised the importance of Popham's evidence, attaching the letters to the published version of The Discoverie as an appendix. ${ }^{72}$ As I have already suggested, the acquisition of Spanish secrets about the New World, especially in the form of captured documentation, represented a compelling form of evidence in late sixteenth-century England. Ralegh suggested in the introduction to the appendix, that the captured letters 'confirme in some parte the substance, [..] the riches of that Countrey'. As the letters appeared to corroborate Ralegh's account of Guiana, he thought it 'fitte that they shoulde be thereunto adjoyned' ${ }^{73}$ Ralegh also made the strategic decision to record the letters verbatim in an appendix, rather than try and incorporate the material into the main text. This decision was not driven by time constraints but by authorial calculation. ${ }^{74}$ Ralegh, like Hakluyt before him, hoped that by presenting these materials intact 
and without alteration, and by leaving them open 'to the consideration and judgement of the indifferent reader', they would be received more favourably. ${ }^{75}$

In the introduction to the letters, Ralegh also attempted to connect their content with Martín's story. He reminded his readers that 'the Spanyardes seeme to call Guiana and other Countries neere it, bordering upon the Orenoque, by the name of Nuevo Dorado, because of the greate plenty of Golde there' ${ }^{76}$ Skipping over the fact that 'Nuevo Dorado' and 'El Dorado' did not necessarily mean the same thing, Ralegh claimed that the fact these letters referred to a 'Dorado' in some form meant they were 'alluding also to the name of El Dorado which was given by Martínes to the greate Citie of Manoa', ${ }^{77}$ Ralegh, therefore, performed yet another sleight of hand in relation to the naming of Manoa, whether intentionally or not. Manoa was, according to Ralegh, not only known as 'El Dorado' amongst the Spanish, but also as 'Nuevo Dorado'. Any documentation mentioning these three places, then, could be used to authenticate both Ralegh's vision of a Guianan El Dorado and Martín's account of Manoa from which it was derived. The utility of these documents was contingent on the conflation of Manoa with El Dorado and on their ability to authenticate the problematic eye-witness testimony of Martín.

On their own, the letters appear speculative and ambiguous; the location of El Dorado was imprecise, and none of the writers of these letters had claimed to have direct knowledge of the city's existence. Instead, one writer claimed that he had it 'for certaine' that the golden city had been found as he had 'letters Written from thence by some that were in the discovery'. ${ }^{78}$ In another, the author relied on the fact that the news of the discovery passed 'for good amongst the best of this City', proving, in his mind, its veracity. ${ }^{79}$ Most worryingly of all though, many of these letters seemed to have one man at their centre: Antonio de Berrío, Ralegh's captive in Trindad who had searched for El Dorado in the regions surrounding the Orinoco and who had been the source of the disputed eye-witness testimony of Juan Martín. The most extensive piece included in the appendix was an extract of a report from Domingo 
de Vera y Ibarguen to the King of Spain. De Vera had been involved in Berrío’s expeditions to find El Dorado in the early 1590s. ${ }^{80}$ Unsurprisingly, de Vera was convinced of the golden city's existence and Berrío's claims to have discovered it. As de Vera wrote, 'Anth. De Berreo, with the travel of 11 yeares, and expence of more than 100000. Pesos of Gold, discovered the royall provinces of Guiana and Dorado' ${ }^{81}$ In another letter composed by 'Certaine Marchantes of Rio de Hacha', Berrío was once again named as the principal source of their information. According to these merchants, a certain province 'so rich in Gold as the report thereof may seeme incredible' had lately been discovered. The new province was named 'Nuevo Dorado' and 'Anthonio de Berreo made the said discovery'. ${ }^{82}$

Once again, this set of seemingly corroborating evidence had the insidious presence of Ralegh's prisoner lurking in the background. Ralegh's supporting evidence for the existence of the golden empire, although utilising innovative techniques of collection and presentation that had been tried and tested by other sixteenth-century travel writers, continued to rely on the conflation of Manoa with El Dorado and on the acceptance of the credibility of both Berrío and Martín's testimony. This evidence, and Ralegh's use of it to corroborate his vision of a Guianan El Dorado, was entirely determined by the contingent specifics of what he knew, or thought he knew.

When extracting this contingent evidence from Ralegh's narrative, what remains to support his claims appears to be exceedingly thin. If his readers were not willing to accept that Martín's story was accurate and that the El Dorado that the Spanish sought in the Amazon was the same place as the Manoa that Ralegh hoped to discover, how else could they be convinced of the validity of a Guianan El Dorado, and reassured that, should they invest, the Empire lay ready to be conquered and exploited by the English? Ralegh was left with one final strategic approach; to convince his readers of his reliability as an eye-witness. 
Ralegh knew that the testimony of Martín and Berrío would not be enough to convince his sceptics of the existence of El Dorado. After all, Ralegh had been circulating this information since his return to England, well before the publication of The Discoverie. ${ }^{83}$ As Ralegh made clear, this information had not been received well back home. Ralegh complained that anything written by him would require 'double' the 'protection and defence' as many would object to his account 'out of malice' and 'revenge'. ${ }^{84}$ Whilst Ralegh did not name his critics, he gave his readers an indication of the kind of rumours that they had been spreading since he returned home from the New World. They had claimed that Ralegh had either 'hidden in cornwell', been 'a servant to the Spanish king', or bought 'gold oar in Barbery' to pass off as the gold of El Dorado. ${ }^{85}$ When Ralegh published his account in 1596, then, his position as a credible eye-witness was on shaky ground.

The reason for this poor reception, aside from the fact that much of Ralegh's information came from disputed Spanish sources, was Ralegh himself. Ralegh had produced, as we shall see, very little original evidence of his own and, since his indiscretion with Elizabeth Throckmorton and subsequent courtly disgrace, he had been unable to shake off the reputation of being inherently deceitful and untrustworthy. In 1591 Ralegh had secretly married Elizabeth Throckmorton, one of Elizabeth I's ladies in waiting, without royal permission. When the marriage was discovered Ralegh was thrown into the Tower of London and his reputation was left in tatters. ${ }^{86}$ It was not, however, merely the fact that he had married without the Queen's permission that led to his disgrace. Ralegh's betrayal of the Queen was undoubtedly compounded by his refusal to admit to the marriage, even when many influential men at court were well aware that it had taken place. ${ }^{87}$ In a letter to Robert Cecil from March 1592, written well after his marriage to Elizabeth, Ralegh beseeched his patron and friend to 'suppress' the 'malicious report' that he had married without royal permission. He implored Cecil to 'believe it not' that he was married, assuring him that he swore before God that there was 'none on the 
face of the yearth' that he would 'be fastned unto' in marriage. ${ }^{88}$ Ralegh's reputation amongst some at court was therefore highly damaged in the years preceding the Guiana venture. Mary Fuller has argued that Ralegh hoped the Guiana project would act as penance for his disgrace and restore his position at court. ${ }^{89}$

In order to overcome the overwhelming criticism that circulated on his return to England, Ralegh attempted to provide his readers with some original evidence of El Dorado's existence. The first piece of this 'evidence' is the focal point of Ralegh's address to the reader: the rock samples that he returned home with in 1595. By the end of the sixteenth century explorers were increasingly returning home with artefacts from their travels that would corroborate what they had claimed to have witnessed. The shelves of cabinets of curiosities swarmed with an array of objects brought back from distant lands, from mineral, animal and plant specimens, to cultural artefacts such as canoes, native weaponry and ritual tobacco pipes. $^{90}$

It is also likely that Ralegh knew that one way to secure further investment in a New World project was to return home with physical proof of gold. This had, for example, been the case with Martin Frobisher's voyages to the far north of the American continent in the 1570s. Michael Lok, one of the venture's principal investors, described receiving a piece of black rock that had been collected on the first voyage to Meta Incognita in $1576 .{ }^{91}$ According to Lok, a number of trials were made of the rock by the experimental Venetian alchemist, Giovan Battista Agnello. As Lok suggested, 'mutch mervaile was made' about the rock as Agnello had concluded that the unpromising black specimen was in fact a 'peace of a mynerall Ewre of a gold myne'. The story of 'Frobisher's Gold' as it became known, spread throughout Elizabethan London, sparking an increase in investment for voyages to the New World that went in search of gold, including a second voyage undertaken by Frobisher in 1577 and a third in $1578 .^{92}$ After this third voyage, it was quickly realised that the ore that Frobisher had brought 
to England was in fact worthless, being nothing more than iron pyrite. With the realisation that there was no gold to be found in the Far North, investment for Frobisher's venture dried up and the project was eventually abandoned. ${ }^{93}$

Unfortunately for Ralegh, the samples he returned home with had also turned out to be mostly worthless. Ralegh bemoaned the fact that his Guiana samples had been met with 'divers opinions' relating to its quality and worth. He also told his readers that due to 'malicious slaunder' he felt it necessary to explain in more detail the trials of the ore that had taken place in London. ${ }^{94}$ The first issue he tackled was the fact that many of his company had returned home with Marcasite, having mistaken it for gold. Ralegh explained how he had told his fellow voyagers that these rocks were 'of no riches or value' but that they chose to trust in their 'owne sence', rather than listen to his opinion..$^{95}$ Once back in England, and to Ralegh's obvious displeasure, these members of the expedition had had trials made of the worthless rock, leading to the accusations that there was no gold to be had in Guiana. ${ }^{96}$ The problems continued after he had his own specimens analysed by assayers. According to Ralegh, his assayers seemed to have suggested that the ore he had brought home was of some value, and yet the Alderman of London seemed to disagree. Ralegh complained that the Alderman had detrimentally damaged his enterprise because, as he was not 'presented with the best' of the Guianan ore, he did 'scandall all the rest'. ${ }^{97}$ Ralegh also had to explain why he did not return home with more ore, if he was so sure that it was valuable. He reminded his readers that it was not easy to remove gold 'out in heapes' and that even if the mountains of Guiana had 'beene of massie gold' it remained impossible, due to the poor weather conditions, for he and his men to remain in the region any longer to 'wrought the same'. ${ }^{98}$ Ralegh's samples had thus not had the impact he had hoped for. Arguably they had made things worse, increasing suspicion amongst his detractors that Ralegh's El Dorado was nothing more than a fantasy. His voyage was a fool's errand and he had returned home with nothing more than fool's gold. 
Ralegh, however, did attempt to mitigate the problems surrounding the samples by deferring to his own autopsy. This was perhaps not the most persuasive strategy, given the fact that many at court already thought him untrustworthy. Ralegh explained that he had witnessed 'divers hils' of white Sparre 'in sundrie places' that he was sure would contain grains of gold, but having 'neither tyme, nor men, nor instruments' he was unable to take samples. ${ }^{99}$ Ralegh also claimed to have seen natives with equipment used for gold mining. On the banks of the Orinoco he saw Indians carrying 'quicksilver, saltpetre, and divers things for the trial of metals'. ${ }^{100}$ From this, Ralegh concluded that there must be a significant gold mine located in the vicinity of the regions that he had explored. The gold of Guiana, however, remained frustratingly outside Ralegh's grasp. He could only offer his readers the narrowest glimpse of the potential wealth and abundance of El Dorado. What he could not offer was a sustained and credible gaze of the hidden golden city.

\section{Conclusion}

Ralegh's attempts at authenticating his belief in a Guianan El Dorado illustrate how fragile knowledge production about the New World was at the end of the sixteenth century. Despite new forms of 'evidence' being deemed reliable, from the acquisition of physical evidence, to the use of historical fragments and captured Spanish documentation, Ralegh's deployment of this kind of material remained problematic. Unlike his compatriots Hakluyt and Frobisher who had successfully illustrated how material proof and second-hand eye-witness testimony could be used to build confidence in English overseas activity, Ralegh struggled to deploy a range of 'evidence' in The Discoverie. Popham's letters reinforced the centrality of Ralegh's prisoner Berrío in the narrative of the search for Manoa, Ralegh's worthless samples of ore strengthened his critics' claims that the region he had explored was not home to a hidden city of extraordinary wealth, and his use of fragments of evidence surrounding the Spanish conquest 
of Peru served only to throw into stark relief the missing pieces of information from Martín's account of El Dorado. Ralegh's failed attempts at utilising these new models of knowledge production in many ways undermined his belief in El Dorado still further.

Ralegh's need to utilise these new forms of evidence, however, stemmed from his inability to procure reliable eye-witness testimony, whether first-hand or second. What Ralegh's narrative suggests is that in the late sixteenth century credible eye-witness testimony was a crucial ingredient for the authentication of travel narratives, especially when other types of evidence such as physical proof was lacking. Ralegh's text also elucidates exactly what constituted reliable testimony at the close of the sixteenth century. The appeal to first-hand experience was not enough to convince sceptical critics of the reliability of Ralegh's eyewitness testimony. Ralegh's poor reputation, the equally damaged reputations of his Spanish informants Berrío and Martín, and the negative reception of Ralegh's ideas back in England, illustrates that reputational models of authority were still integral to the construction of credible eye-witness accounts of the New World. Ralegh's own concerns surrounding his reputation, moreover, throw into starker relief the importance of reputation in early modern society more broadly. Reputation formed a critical aspect of early modern identity, dictating economic status, sexual honour, intellectual prowess, and, in the case of early modern travel writers, notions of authentic discovery. Without convincing autopsy, either first-hand or second, Ralegh's belief in a Guianan E1 Dorado remained unconvincing.

Ralegh's failed attempts at mitigating his poor reputation also suggests that systems of knowledge production, especially in the context of New World discoveries, remained in flux at the end of the sixteenth century, with older reputational models of authentication being used alongside more innovative forms of evidence. The European 'discovery' of America, as Ralegh's narrative illustrates, did not usher in a new epistemology of travel writing that lauded experience over all other forms of knowledge, but rather instigated a period of confrontation, 
compromise, and co-existence between competing frameworks of knowledge. When Ralegh had set sail he had hoped to discover an empire rich in gold that lay ready to be conquered by the English. In reality, what he discovered was the difficulties and pitfalls that beset those who attempted to present new and credible knowledge about the New World to an increasingly sceptical readership.

\section{Bibliography}

\section{Published Primary Sources}

Anon. The Strange and Marveilous Newes Lately Come from the Great Kingdome of Chyna, translated by Thomas Nicholls. London, 1577.

Cartier, Jacques. “Cartier's Second Voyage.” In The Voyages of Jacques Cartier, edited by Ramsay Cook, 35-95. Toronto: University of Toronto Press, 1993.

Castellanos, Juan de, Elegías Para Varones Ilustres de las Indias, edited by Buenaventura Carlos Aribau. Madrid, 1852.

Evesham, John. "A Voyage to the Azores with Two Pinases." In The Principal Navigations, Voyages, Traffiques and Discoveries of the English Nation, $2^{\text {nd }}$ edition, edited by Richard Hakluyt, 2: 120-121. London, 1598-1600.

Fernández de Oviedo, Gonzalo. "Appendix C." In Fernández de Oviedo's Chronicle of America: A New History for a New World, edited by Kathleen Myers and translated by Nina M. Scott, 143-179. Austin: University of Texas Press, 2007.

Hakluyt, Richard, ed. The Principal Navigations, Voyages, Traffiques and Discoveries of the English Nation. London, 1589.

Lok, Michael. "Michael Lok's Testimony." In The Third Voyage of Martin Frobisher to Baffin Isalnd, 1578, edited by James McDermott, 71-102. London: The Hakluyt Society, 2001.

Ralegh, Sir Walter. The Discoverie of the Large, Rich, and Bewtiful Empyre of Guiana. London, 1596.

Ralegh, Sir Walter to Sir Robert Cecil. "Preparations for a Naval Expedition and Ralegh's Marriage, March 1592." In The Letters of Sir Walter Ralegh, edited by Agnes Latham and Joyce Youings, 63-64. Exeter: University of Exeter Press, 1999.

Smith, John. Advertisements for the Unexperienced Planters of New-England. London, 1631. 


\section{Secondary Sources}

Adorno, Rolena. "The Discursive Encounter of Spain and America: The Authority of Eyewitness Testimony in the Writing of History." William and Mary Quarterly 49, no. 2 (1992): 210-228.

Andrews, Kenneth R. Trade, Plunder and Settlement: Maritime Enterprise and the Genesis of the British Empire, 1480-1630. Cambridge: Cambridge University Press, 1984.

Barker, S. K., and Brenda M. Hosington, eds. Renaissance Cultural Crossroads: Translation, Print and Culture in Britain, 1473-1640. Leiden: Brill, 2013.

Batho, G. R. “Jacob Whiddon.” ODNB. Last accessed 16 September, 2017. http://www.oxforddnb.com/view/article/29205.

Billings, Warren M. Jamestown and the Founding of the Nation. Gettysburg, PA: Thomas Publications, 1990.

Bryson, Alan. "Elizabethan Verse Libel." In The Oxford Handbook of the Age of Shakespeare, edited by R. Malcolm Smuts, 477-492. Oxford: Oxford University Press, 2016.

Burke, Peter, and R. Po-chia Hsia, eds. Cultural Translation in Early Modern Europe. Cambridge: Cambridge University Press, 2007.

Byrd Simpson, Lesley. "Introduction." In Cortés: The Life of the Conqueror and His Secretary Francisco López de Gómara, edited and translated by Lesley Byrd Simpson, xv-xxvi. Berkeley, CA: University of California Press, 1964.

Campbell, Mary B. The Witness and the Other World: Exotic European Travel Writing, 4001600. Ithaca, NY: Cornell University Press, 1988.

Cobo Borda, Juan Gustavo. Fabulas y Leyendas de El Dorado. Barcelona: Tusquets Circulo, 1987.

Cook, Alexandra Parma, and Noble David Cook. "Introduction." In The Discovery and Conquest of Peru: Chronicles of the New World Encounter by Pedro Cieza de León, edited and translated by Alexandra Parma Cook and Noble David Cook, 5-35. Durham, NC: Duke University Press, 1998).

Frisch, Andrea. The Invention of the Eyewitness: Witnessing and Testimony in Early Modern France. Chapel Hill: University of North Carolina Press, 2004.

Fuller, Mary C. Voyages in Print: English Travel to America, 1576-1624. Cambridge: Cambridge University Press, 1995.

Gowing, Laura. Domestic Dangers: Women, Words, and Sex in Early Modern London. Oxford: Oxford University Press, 1999.

Grafton, Anthony. New Worlds, Ancient Texts: The Power of Tradition and the Shock of Discovery. Cambridge, MA: Harvard University Press, 1992. 
Greenblatt, Stephen. Marvellous Possessions: The Wonder of the New World. Chicago: University of Chicago Press, 1991.

Greenblatt, Stephen. Sir Walter Ralegh: The Renaissance Man and His Roles. New Haven, CT: Yale University Press, 1973.

Hadfield, Andrew. Literature, Travel and Colonial Writing in the English Renaissance.

Oxford: Oxford University Press, 2007.

Harkness, Deborah E. The Jewel House: Elizabethan London and the Scientific Revolution. New Haven, CT: Yale University Press, 2007.

Hart, Jonathan. Empires and Colonies. Cambridge: Polity, 2008.

Hemming, John. The Search for El Dorado. London: Phoenix Press, 2001.

Hodgen, Margaret. Early Anthropology in the $16^{\text {th }}$ and $17^{\text {th }}$ Centuries. Philadelphia: University of Pennsylvania Press, 1964.

Kupperman, Karen Ordahl. The Jamestown Project. Cambridge, MA: Harvard University Press, 2007.

Kupperman, Karen Ordahl. Roanoke: The Abandoned Colony. Second edition. Lanham, MD: Rowman \& Littlefield, 2007.

Lamikiz, Xabier. Trade and Trust in the Eighteenth-Century Atlantic World: Spanish Merchants and their Overseas Networks. Woodbridge, UK; Boydell Press, 2010.

Lewis, Bart L. The Miraculous Lie: Lope de Aguirré and the Search for El Dorado in the Latin American Novel. Lanham, MD: Lexington Books, 2003.

Lorimer, Joyce. "Introduction.” In Sir Walter Ralegh's Discoverie of Guiana, edited by Joyce Lorimer, xvii-xcvi. London: The Hakluyt Society, 2006.

Maczelka, Csaba. "Exile, Translation, and Authorial Self-Representation in Elizabethan Travel Literature: The Case of Thomas Nicholls." In Displacing the Anxieties of Our World: Spaces of the Imagination, edited by Ildikó Limpár, 44-62. Newcastle upon Tyne: Cambridge Scholars Publishing, 2017.

Magasich-Airola, Jorge, and Jean-Marc de Beer. America Magica: When Renaissance Europe Thought it Had Conquered Paradise, edited and translated by Monica Sandor. London: Anthem Press, 2007.

Mancall, Peter C. Hakluyt's Promise: An Elizabethan's Obsession for an English America. New Haven, CT: Yale University Press, 2007.

McDermott, James. Martín Frobisher: Elizabethan Privateer. New Haven, CT: Yale University Press, 2001.

McGhee, Robert. The Arctic Voyages of Martín Frobisher: An Elizabethan Adventure. London: British Museum Press, 2001. 
Miller, Shannon. Invested with Meaning: The Raleigh Circle in the New World. Philadelphia: University of Pennsylvania Press, 1998.

Montrose, Louis. "The Work of Gender in the Discourse of Discovery." In New World Encounters, edited by Stephen Greenblatt, 177-217. Berkeley CA: University of California Press, 1993.

Muldrew, Craig. The Economy of Obligation: The Culture of Credit and Social Relations in Early Modern England. Basingstoke: Macmillan, 1998.

Naipaul, V. S. The Loss of El Dorado: A Colonial History. London: Picador, 2001.

Nicholl, Charles. The Creature in the Map: Sir Walter Ralegh's Quest for El Dorado. New York: William Morrow and Co., 1996.

Pagden, Anthony. European Encounters with the New World. New Haven, CT: Yale University Press, 1993.

Perera, Miguel Angel. Oro y Hambre: Guayana Siglo XVI: Antropología Histórica y Ecología Cultural de un Malentendido, 1498-1597. Caracas: Universidad Central de Venezuela, 2000.

Popper, Nicholas. Walter Ralegh's History of the World and the Historical Culture of the Late Renaissance. Chicago: University of Chicago Press, 2012.

Quinn, David B. Ralegh and the British Empire. London: Penguin, 1962.

- Set Fair for Roanoke: Voyages and Colonies, 1584-1606. Chapel Hill, NC: University of North Carolina Press, 1985.

- England and the Discovery of America, 1481-1620. Sydney: Allen \& Unwin, 1974.

Sanchez, Mark G. "Anti-Spanish Sentiment in English Literary and Political Writing, 15531603." PhD dissertation, University of Leeds, 2004.

Schaffer, Simon and Steven Shapin, Leviathan and the Air-Pump: Hobbes, Boyle, and the Experimental Life. Princeton: Princeton University Press, 1986.

Shapin, Steven, A Social History of Truth: Civility and Science in Seventeenth-Century England. Chicago: University of Chicago Press, 1994.

Shelton, Anthony Alan, 'Cabinets of Transgression: Renaissance Collections and the Incorporation of the New World', in John Elsner and Roger Cardinal, eds., The Cultures of Collecting (London, 1994), pp. 177-203.

Shepard, Alexandra. Accounting for Oneself: Worth, Status, and the Social Order in Early Modern England. Oxford: Oxford University Press, 2015.

Silverberg, Robert. The Golden Dream: Seekers of El Dorado. Athens: Ohio University Press, 1996.

Small, Margaret. "A World Seen Through Another's Eyes: Hakluyt, Ramusio, and the Narratives of the Navigationi et Viaggi." In Richard Hakluyt and Travel Writing in Early Modern Europe, edited by Daniel Carey and Claire Jowitt, 45-55. Farnham: Routledge, 2012. 
Smith, D. K. The Cartographic Imagination in Early Modern England: Re-writing the World in Marlowe, Spenser, Raleigh and Marvell. Aldershot: Routledge, 2008.

von Hagen, Victor W. The Golden Man: A Quest for El Dorado. Farnborough: Saxon House, 1974.

Wennerlind, Carl. Casualties of Credit: The English Financial Revolution, 1620-1720. Cambridge, MA: Harvard University Press, 2011.

Whitehead, Neil. "The Discoverie as Ethnological Text." In The Discoverie of the Large, Rich, and Bewtiful Empyre of Guiana by Sir Walter Ralegh, edited by Neil Whitehead, 60116. Manchester: Manchester University Press, 1997.

Williams, Penry, and Mark Nicholls. Sir Walter Raleigh in Life and Legend. London: Bloomsbury Continuum, 2011.

Yenne, Bill. Cities of Gold: Legendary Kingdoms, Quixotic Quests, and the Search for Fantastic New World Wealth. Yardley, PA: Westholme Publishing, 2013.

\section{Notes}

\footnotetext{
${ }^{1}$ Ralegh, The Discoverie, frontispiece.

2 Ibid., sigs. A3r-II3v.

${ }^{3}$ Ibid., sig. II2r and sig. I[4r.

${ }^{4}$ Adorno, "The Discursive Encounter", 210-228; Campbell, The Witness and the Other World; Greenblatt, Marvellous Possessions; Pagden, European Encounters; Small, “A World Seen Through Another's Eyes”; Kupperman, Jamestown Project, 136-139.

${ }^{5}$ Kupperman, Jamestown Project, 136.

${ }^{6}$ Cartier, “Cartier's Second Voyage”, 36; Smith, Advertisements for the Unexperienced Planters, 32.

${ }^{7}$ Scholarship on these new forms of evidence includes: Grafton, New Worlds, Ancient Texts; Popper, Ralegh's History of the World; Small, “A World Seen Through Another's Eyes"; Shelton, "Cabinets of Transgression”, 77-203; D. Smith, The Cartographic Imagination.

${ }^{8}$ For scholarship that has utilised eye-witness accounts of the Americas as proof of the epistemological centrality of firsthand experience in the sixteenth century see: Adorno, "The Discursive Encounter", 210-228; Campbell, The Witness and the Other World; Greenblatt, Marvellous Possessions; Pagden, European Encounters; Small, “A World Seen Through Another's Eyes”. Andrea Frisch has recently complicated understandings of eye-witness testimony by tracing the process by which 'ethical' models of witnessing were
} 
replaced by 'epistemic' models that prioritised experience. Information from Frisch, Invention of the Eyewitness.

${ }^{9}$ Muldrew, Economy of Obligation; Shepard, Accounting for Oneself; Lamikiz, Trade and Trust; Wennerlind, Casualties of Credit; Schaffer and Shapin, Leviathan and the Air-Pump; Shapin, Social History of Truth.

${ }^{10}$ Muldrew, Economy of Obligation, 148.

${ }^{11}$ Joyce Lorimer has recently uncovered a variety of ways in which Ralegh attempted to endear his venture to sceptical readers back in England. In particular, Lorimer argues that Ralegh was forced by his patron and editor Robert Cecil to place more emphasis on workable gold mines, rather than the wealth of Guiana, in the published version of the text. Lorimer, "Introduction", xxiv-xxxv.

${ }^{12}$ Examples of scholarship where Ralegh's voyage is presented as being intrinsically linked to his wider biography include: Fuller, Voyages in Print, 55-84; Greenblatt, Sir Walter Ralegh, 99-126; Nicholls and Williams, Sir Walter Raleigh in Life and Legend, 99-118; Quinn, Ralegh and the British Empire, 162-208. Scholarship that has placed Ralegh's voyage within the wider narrative of European searches for El Dorado includes: Cobo Borda, Fabulas y Leyendas; Hemming, The Search for El Dorado; Silverberg, The Golden Dream; von Hagen, The Golden Man; Yenne, Cities of Gold: There are, of course, some excellent studies on The Discoverie and its wider implications. These include: Campbell, The Witness and the Other World, 211254; Montrose, "The Work of Gender"; Whitehead, "The Discoverie as Ethnological Text”, 60-116.

${ }^{13}$ A similar argument has been made by Anthony Grafton through his analysis of the resilience of classical authorities in the wake of 1492 . He too argues that this was a period in which systems of knowledge production were in flux, being reliant on both new techniques of collection and collation and older models of authority and tradition: Grafton, New Worlds, Ancient Texts.

${ }^{14}$ Ralegh, The Discoverie, 10.

${ }^{15}$ Ibid. 10-16.

${ }^{16}$ For information on the Muisca origins of the El Dorado legend see: Magasich-Airola and de Beer, America Magica, 71-74.

${ }^{17}$ Castellanos, Elegías Para Varones Ilustres, 453.

${ }^{18}$ Ralegh, The Discoverie, sig. A3v.

${ }^{19}$ Hemming, Search for El Dorado, 183; Lorimer, "Introduction," xli; Nicholl, Creature in the Map, 34;

Nicholls and Williams, Life and Legend, 100; Quinn, Ralegh, 165-166. For a contemporary account of Sarmiento's capture see: Evesham, "A Voyage to the Azores", 2:120-121.

${ }^{20}$ Hemming, Search for El Dorado, 183; Nicholls, Creature in the Map, 32.

${ }^{21}$ Andrews, Trade, Plunder and Settlement, 189; Batho, "Jacob Whiddon".

${ }^{22}$ Ralegh, The Discoverie, 8.

${ }^{23}$ Ralegh, The Discoverie, 5.

${ }^{24}$ Ibid., 6-7. 
${ }^{25}$ This renaming of El Dorado to Manoa was the result of a mistranslation. In the language of the Achagua 'manoa' simply meant lake. Information from Hemming, Search for El Dorado, 169.

${ }^{26}$ Ralegh, The Discoverie, 16.

${ }^{27}$ Castellanos, Elegías, 453; Hemming, Search for El Dorado, 178; Lewis, The Miraculous Lie, 37; Perera, Oro y Hambre, 318.

${ }^{28}$ Ralegh, The Discoverie, 13-14.

${ }^{29}$ Ibid., 13-16.

${ }^{30}$ It is also possible that the word 'tract' refers to a piece of land, rather than Martín's account, making it even more unclear whether Ralegh had actually read Martín's testimony: Ralegh, The Discoverie, 16.

${ }^{31}$ Ibid

${ }^{32}$ Campbell, The Witness and the Other World, 2.

${ }^{33}$ Hodgen, Early Anthropology, 16-107.

${ }^{34}$ As Margaret Small has recently put it, by the end of the sixteenth century 'autopsy endowed authority'. From Small, “A World Seen Through Another's Eyes”, 49.

${ }^{35}$ Castellanos, Elegías, 453-454.

${ }^{36}$ Ibid.

${ }^{37}$ Ibid., 453.

${ }^{38}$ Hemming, Search for El Dorado, 178.

${ }^{39}$ Naipaul, The Loss of El Dorado, 17.

${ }^{40}$ For more detail on these legends see Magasich-Airola and de Beer, America Magica, 48-79.

${ }^{41}$ Ralegh, The Discoverie, 15-16.

${ }^{42}$ Ibid., 16.

${ }^{43}$ For scholarship on Renaissance translation see: Burke and Hsia, Cultural Translation; Barker and Hosington, Renaissance Cultural Crossroads; Hadfield, Literature, Travel and Colonial Writing.

${ }^{44}$ For an example of Hakluyt printing his translations alongside the original see Hakluyt, Principal Navigations, $1: 14-15$.

${ }^{45}$ Ibid., sig. *3v.

${ }^{46}$ Small, "A World Seen Through Another's Eyes”, 54.

${ }^{47}$ Ralegh, The Discoverie, 13-16. 
${ }^{48}$ There is evidence to suggest that Ralegh may not have read Martín's account at all and that the information he received about Martín came from Berrío. For example, Ralegh stated that it is from Berrío that he learned that Martín had christened Manoa 'El Dorado'. Berrío therefore influenced Ralegh's rendering of the story to at least some degree. Information from Ralegh, The Discoverie, 16.

${ }^{49}$ Frisch, Invention of the Eyewitness, 41-53.

${ }^{50}$ Ibid., 129-132.

${ }^{51}$ For reputation and economic status see Muldrew, Economy of Obligation; for reputation and sexual honour see Gowing, Domestic Dangers; for reputation and the pursuit of scientific knowledge see Shapin, Social History of Truth.

${ }^{52}$ An early use of this technique can be seen in Anon., Strange and Marveilous Newes. This text is a translation of a captured Spanish letter that was intended for the King of Spain. The translator, Nicholls, was working under the patronage of Francis Walsingham who was well-known for his virulent anti-Catholicism. By publishing Spain's secrets Walsingham could not only undermine the Spanish, but could also provide English explorers with useful information that may aid their own plans. For more information on Nicholls and Walsingham see Maczelka, "Exile, Translation, and Authorial Self-Representation", 44-62; Hart, Empires and Colonies, 63-69; Sanchez, "Anti-Spanish Sentiment”, 142-177.

${ }^{53}$ Hakluyt, Principal Navigations, $2^{\text {nd }}$ edition, sigs. 3:A2r-A3v.

${ }^{54}$ Ibid., sig. A2v.

${ }^{55}$ Ibid.

${ }^{56}$ Ralegh, The Discoverie, 6-7.

${ }^{57}$ Ibid., 51.

${ }^{58}$ Ibid., 33-34.

${ }^{59}$ Ibid., 51-52.

${ }^{60}$ Louis Montrose has made a similar point about Ralegh's use of Spanish evidence and Spanish behaviour. Montrose argues that Ralegh obfuscates this paradoxical representation of the Spaniard by making an absolute distinction between the sexual conduct of the Spanish and the English. It is my contention, however, that Ralegh never successfully obscures this unstable image of the Spaniard. Information from Montrose, "The Work of Gender", 16-17.

${ }^{61}$ For a detailed analysis of the scholarly strategies employed by Ralegh in The History of the World see Popper, Walter Ralegh's History of the World.

${ }^{62}$ Ibid., $1-8$.

${ }^{63}$ Ralegh, The Discoverie, 9.

${ }^{64}$ Ibid., 9-10. 
${ }^{65}$ Ibid., 10.

${ }^{66}$ Ibid.

${ }^{67}$ Ibid.

${ }^{68}$ León was a conquistador who was involved in a number of Spanish expeditions. He later settled in Peru where he began to compose his chronicle of the country, with the first part being published in 1553. Gómara was chaplain to Hernán Cortés and had direct access to a range of eye-witness testimony of the New World for his Historia general de las Indias which was published in Zaragoza in 1552. For more information on León and Gómara see Cook and Cook, "Introduction", 5-35; Simpson, "Introduction", xx. Quotation taken from Ralegh, The Discoverie, 10-11.

${ }^{69}$ Ralegh, The Discoverie, 11-12.

${ }^{70}$ For information on the association between Hakluyt and Ralegh see Mancall, Hakluyt's Promise, 175-177 and 255. Ralegh's inclusion of the original Spanish can be found in Ralegh, The Discoverie, 11.

${ }^{71}$ Lorimer, "Introduction”, xliv-xlvii.

${ }^{72}$ Ralegh, The Discoverie, 102-112.

${ }^{73}$ Ibid., 103.

${ }^{74}$ Lorimer, "Introduction", xlvii.

${ }^{75}$ Ralegh, The Discoverie, 104.

${ }^{76}$ Ibid.

${ }^{77}$ The use of the adjective 'nuevo' meaning 'new' to describe the 'Dorado' to be found in Guiana implicitly alludes to the fact that the existence of 'El Dorado' was an earlier tradition that focused on a different region of the New World. Quotation from Ralegh, The Discoverie, 104.

${ }^{78}$ Ralegh, The Discoverie, 105.

${ }^{79}$ Ibid., 110.

${ }^{80}$ Hemming, Search for El Dorado, 176.

${ }^{81}$ Ralegh, The Discoverie, 106.

${ }^{82}$ Ibid., 111-112.

${ }^{83}$ Lorimer, "Introduction", xxiv

${ }^{84}$ Ralegh, The Discoverie, sigs. A2r-A2v.

${ }^{85}$ Ibid., sigs. A3r and $\llbracket[3 \mathrm{v}$.

${ }^{86}$ Nicholls and Williams, Sir Walter Raleigh, 74-77. 
${ }^{87}$ The marriage took place before 19 November 1591 as this is when Elizabeth's father, Arthur Throckmorton, heard of the marriage. Information from Nicholls and Williams, Sir Walter Raleigh, 76.

${ }^{88}$ As Agnes Latham and Joyce Youings have suggested in their annotations to this letter, by the time of its composition it was likely that many in high places were already aware of the marriage. Information and quotations from Ralegh, "Preparations for a Naval Expedition”, 63-64.

${ }^{89}$ Fuller, Voyages in Print, 74.

${ }^{90}$ Grafton, New Worlds, 217-222.

${ }^{91}$ Harkness, The Jewel House, 142.

${ }^{92}$ Michael Lok, "Michael Lok’s testimony", 72-73.Ftract

${ }^{93}$ McGhee, Arctic Voyages, 140-147.

${ }^{94}$ Ralegh, The Discoverie, sig. I[2r.

${ }^{95}$ Ibid.

${ }^{96}$ Ibid.

${ }^{97}$ Ibid., sig. I[2v.

${ }^{98}$ Ibid., sig. I[3r.

${ }^{99}$ Ibid., sig. $92 \mathrm{v}$.

${ }^{100}$ Ibid., 49. 